Science, Technology and Development 35 (2): 67-74, 2016

ISSN 0254-6418 / DOI: 10.3923/std.2016.67.74

(c) 2016 Pakistan Council for Science and Technology

\title{
Tree Communities Analysis of Sheikh Buddin National Park, District Dera Ismail Khan, Pakistan
}

\author{
Attaullah, Nasrullah Khan and Zahid Muhammad \\ Laboratory of Plant Ecology, Department of Botany, University of Malakand, Pakistan
}

\begin{abstract}
The present stduy is aimed to study the phytosociological attributes of the Sheikh Buddin National Park, situated in district Dera Ismail Khan. For this study, various field tours were conducted in March, 2013-August, 2015. A total of 26 plant species belonging to 22 generas and 19 families were identified. The data was collected, using quadrate method. The park was divided in 29 stands and 25 quadrates sized $(10 \times 10 \mathrm{~m})$ were examined in each stand. Vegetation parameters such as Diameter at Breast Height (DBH), density, frequency and Important Value Index (IVI) of the woody species were recorded. The communities generated on the basis of IVI values resulted in the isolation of seven tree communities. Acacia modesta followed by Olea ferruginea were the dominant communities of the study area. Acacia modesta, Olea ferruginea, Acacia nilotiea, Caperis decidua, Tamarix aphylla, Prosopis cineraria and Ailanthus altissima were common species of the study area, while species such as Acacia nilotica, Tecomella undulate, Ziziphus jujube were randomly distributed. The results revealed that generally the park was dominated by small sized tree species indicating a secondary generation stage and it needs proper management, protection and care.
\end{abstract}

Key words: Tree communities, sheikh buddin national park, Pakistan

\section{INTRODUCTION}

For in situ conservation of diverse native species especially the endangered ones, it is necessary to establish well developed protected areas. These activities are carried out for the purpose of protection, research, education and recreation. Furthermore, these areas provide essential items such as building materials, fuel wood, forage, wild foods and traditional medicines (Belayneh and Demissew, 2011). There are 209,429 protected areas upto 2014 in the world covering an area about 32,868,673 km² (Deguignet et al., 2014). According to WCU (World Conservation Union), it is a natural area selected for the protection of the ecological integrity of one or more ecosystems for the present and upcoming generations (Ahmad and Ann, 2011).

National park is an important figure of protected areas, which is established to protect and conserve specific areas of exceptional biological, geographical and culturally important for scientific, educational and recreational purposes. It is comparatively a large area of outstanding natural and scenic merit interest. The primary objective of the national park is to protect the landscape, biodiversity in its natural environment where public are allowed only for recreation, research and educational purposes. Cutting of trees on large scale, hunting or trapping of birds and animals are prohibited in the Park. The construction of roads, electricity, accommodation amenities and public facilities should be carefully planned so as not to affect the primary objective of a national park's establishment (IUCN., 1990).

From different areas of Pakistan, many workers have presented quantitative phytosociological study (Shaukat et al., 2014; Shaheen et al., 2011; Abbas et al., 2009; Ahmad et al., 2009, etc.) carried out their phytosociological research in different regions of the country. Similarly, a series of studies on national parks of the country by many researchers using different techniques were carried out (Hameed et al., 2002; Ahmad and Ann, 2011; Ahmad et al., 2014; Hussain et al., 2013; Rasheed et al., 2005; Jabeen and Ahmad, 2009; Hussain et al., 2010; Khan et al., 2011a).

As no scientific study was conducted on the vegetation of Sheikh Buddin National Park so far and there is no published literature available which can help the government and non-government organizations in exploration of vegetation, preservation and conservation. Therefore, this research study provides important, baseline and necessary information about the flora of Sheikh Buddin National Park. The aim of the study was to understand the general patterns of vegetation (floristic composition and distribution of the trees ecological communities) in Sheikh Buddin National Park in order to evaluate it as a habitat for different plant communities and recreational purposes.

Study area: In Pakistan, there are 26 national parks, in which Sheikh Buddin National Park is one of the most 


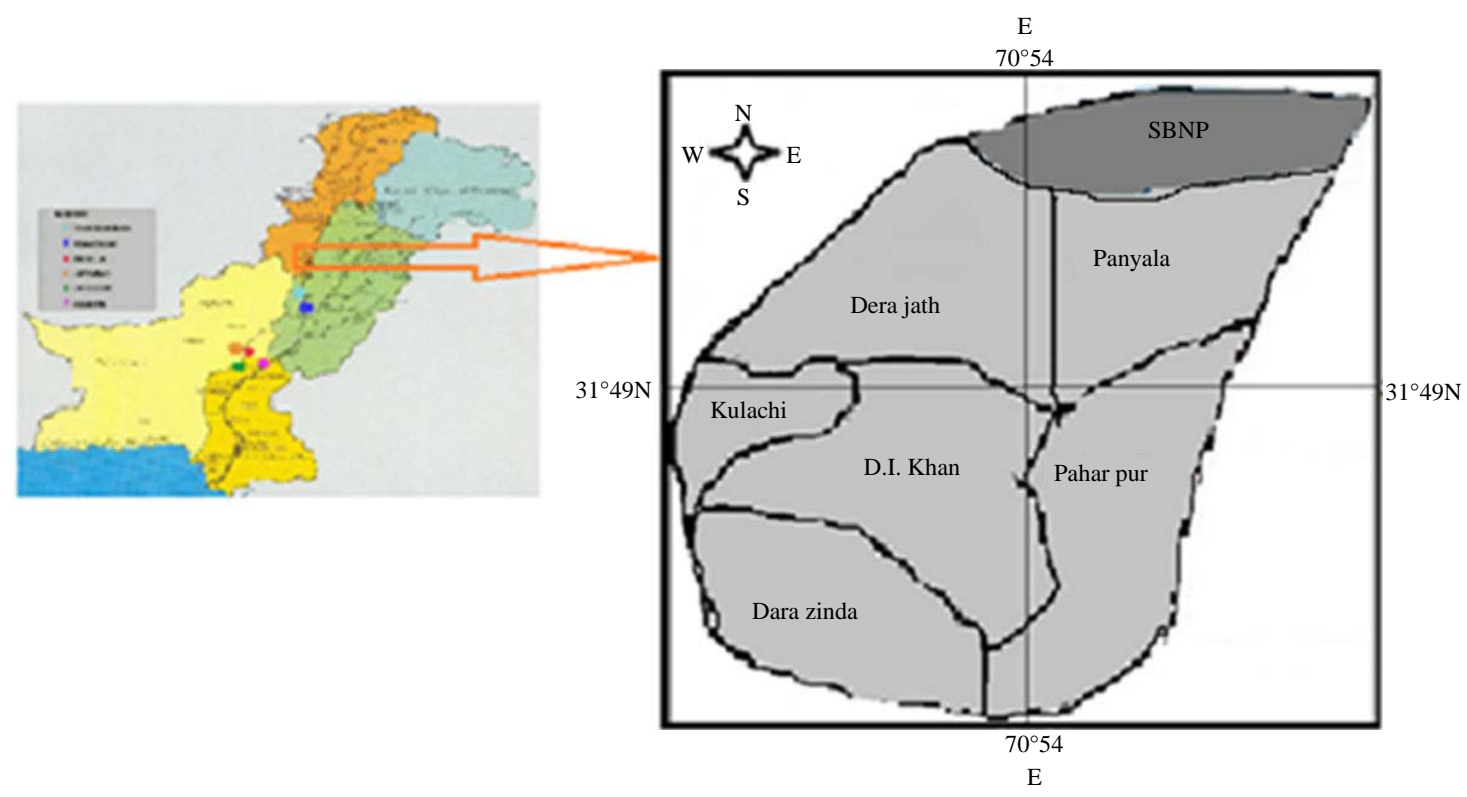

Fig. 1: Map of Dera Ismail Khan District, showing the study area (Shaded)

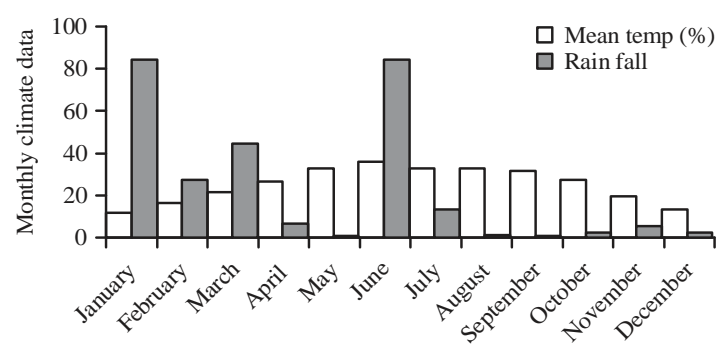

Fig. 2: Metrological data of D.I. Khan District for the year 2013, Source: Wunderground.com

important national parks of Pakistan (Fig. 1). In order to manage, protect, preserve and interpret the park's unique natural, historical and scenic resources and values unimpaired for the education, inspiration and enjoyment purposes for present and future generations, it was upgraded to the status of the national park on 15th July, 1993, via a notification number soft. Forest 1 (FFT) VIII, Peshawar (Ullah et al., 2015). The park is situated in Dera Ismail Khan District of Pakistan, which is the southernmost district of Khyber Pakhtunkhwa (KPK), Pakistan. The districts of Tank and Lakki Marwat are situated in the north of the district, in the south and east, it is bound by Dera Ghazi Khan, Mian Wali and Bhakkar districts of Punjab province and in the west Tribal Area of South Waziristan agency (Marwat and Khan, 2008).

Figure 2 shows that January and July are the coldest and hottest months of the year, respectively. The average maximum and minimum temperatures of winter are
20.3 and $4.2^{\circ} \mathrm{C}$, respectively and 42 and $27^{\circ} \mathrm{C}$ in the summer season. Average annual precipitation of the district is $259 \mathrm{~mm}$ (Marwat et al., 2012).

The Sheikh Buddin hill section, especially, the residential area is located at a distance of about $7 \mathrm{~km}$ from Pezu Bazarpass, District Lakki Marwat. The approximate location of this section is $32^{\circ} 22^{\prime} \mathrm{N}-32^{\circ} 38^{\prime} \mathrm{N}-70^{\circ} 54^{\prime} \mathrm{E}$ $71^{\circ} 12^{\prime} \mathrm{E}$ with an elevation from $300-1350$ meters and covers about a total area of 15,540 hectares. One can access the Pezu Pass via Indus high way from Dera Ismail Khan in south and Lakki Marwat (Nizami and Sheikh, 2009).

\section{MATERIALS AND METHODS}

In order to get the required data, various field tours were arranged during 2013-15. The park was divided into 29 least disturbed stands for sampling. For quantity sampling least healthy and mature vegetation was selected. The plants in each sampling plot were photographed, collected, pressed with the help of presser and were identified with the help of available literature and flora of Pakistan (Ali and Qaiser, 1995-2005, Nasir and Ali, 1971-1995) and finally by comparing with the available specimens in the Herbarium of Botany, University of Malakand, Chakadara, DIR, lower, Pakistan. At last these specimens were deposited in the Herbarium Deportment of Botany, University of Malakand.

For quantitative sampling, data was collected by using quadrate method of Brown and Curtis (1952). For 
trees, $10 \times 10 \mathrm{~m}$ square shape quadrates were taken along a line transect. In each stand 25 quadrates were taken regularly as well as randomly on the basis of slope degree. Thus a total of $725\left(10 \mathrm{~m}^{2}\right)$ quadrates were taken. The height of the trees were determined by Clinometer, however, it was estimated visually when topographic features made it difficult to measure it, while girth at DBH (diameter at breast height) within quadrate was determined by forest tape. Beside trees, shrubs and herbs habitat conditions and physiographic feature, such as altitude, topography, aspect, slope degree and soil features, were also recorded in each sampling plot. Altitude was determined by using GPS (global positioning system); aspect with the help of magnetic compass, while slope was calculated by using a Clinometer.

The information obtained were further analyzed in the laboratory.

Phytosociological attributes: Various ecological parameters such as density, frequency, basal area, relative density and their relative values were determined by following Philips (1959), After getting relative values, Importance Value Index (IVI) was calculated for all the tree species by adding the relative values of frequency, density and basal area and dividing them by 3 , following Curtis and McIntosh (1950), Curtis and Cottam (1956) and Brown and Curtis (1952).

Plant diversity and communities' similarity analysis: Richness was calculated by counting all the species observed in a stand divide by the square root of the total number of individual trees found in a stand following Menhinick’s index (Menhinick, 1964).

$$
\operatorname{Richness}(\mathrm{d})=\frac{\mathrm{S}}{\sqrt{\mathrm{n}}}
$$

Where:

$\mathrm{S}=$ Total No. of species

$\mathrm{n}=$ Total number of individuals of all the species

Shannon index (H') as a measure of species abundance and species richness was used to describe the plant species diversity. Shannon diversity was obtained by calculating the percent density of each species which was divided by 100 and the data was rounded off from this the pi (proportion of the individual's) value was obtained. After that the data was arranged in descending order and natural $\log$ was obtained of the pi values. The natural log was multiplied by pi. All the results were obtained in the same way and were added following Shannon-Weaver Index (Shannon and Weaver, 1949).

$$
\mathrm{H}^{\prime}=-\sum_{\mathrm{i}=1}^{\mathrm{S}} \mathrm{pi} \ln (\mathrm{pi})
$$

Where:

$\mathrm{H}^{\prime}=$ The diversity index

pi $=$ Proportion of individuals (from the sample total) of species I

Simpson diversity (Dominance) was calculated by the formula following Simpson (1949):

$$
\mathrm{D}=\frac{\mathrm{ni}(\mathrm{ni}-1)}{\mathrm{n}(\mathrm{n}-1)}
$$

Where:

$\mathrm{D}=$ Simpson diversity

$\mathrm{ni}=$ No. of individual of a species in a stand and $\mathrm{N}$ is the total No. of all species in a stand

Evenness was estimated by dividing the Shannon effect with natural log of all types of species following (Pielou, 1969) Formula:

$$
\text { Evenness }(\mathrm{J})=\mathrm{H} \nsubseteq / \mathrm{H} \mathbb{m a x}=\mathrm{H} \mathbb{} \log \mathrm{S}
$$

Where:

$\mathrm{S}=$ No. of species

$\mathrm{H} \mathbb{\leftarrow}=$ Observed diversity, $\mathrm{H} \mathbb{} \max =$ maximum diversity

Community similarity with each other was calculated by standard procedure described by Sorenson (1948) by the following formula:

$$
\mathrm{SI}=2 \mathrm{C} / \mathrm{A}+\mathrm{B} \times 100
$$

where, SI represent Sorenson similarity index of 2 communities. $C$ represent number of species common to both communities, A and B represent total number of species of both communities.

\section{RESULTS AND DISCUSSION}

Table 1 represents the communities, total number and distribution of stands in the community. It is clear from Table 1 that community 1 is the largest community having 10 stands, while the communities V, VI and VII were smallest by having one stand each.

Community structure: The communities were named on the basis of most dominant species average IVI values. 
Sci. Technol. Dev., 35 (2): 67-74, 2016

Table 1: Communities and distribution of sample plots in the communities

\begin{tabular}{lllrrr}
\hline Community & No. of stands & No. of plots in the communities & Average elevation & Latitude range & Longitude range \\
\hline I & 10 & $3,4,5,6,7,13,19,20,22,27$ & 592 & $32^{\circ} 17^{\prime}-32^{\circ} 33$ & $70^{\circ} 45^{\prime}-71^{\circ} 10^{\prime}$ \\
II & 7 & $9,12,16,23,24,26,29$ & 805 & $32^{\circ} 16^{\prime}-32^{\circ} 30^{\prime}$ & $70^{\circ} 49^{\prime}-71^{\circ} 11^{\prime}$ \\
III & 6 & $8,14,17,21,25,28$ & 417 & $32^{\circ} 24^{\prime}-32^{\circ} 34^{\prime}$ & $71^{\circ} 05^{\prime}-71^{\circ} 12^{\prime}$ \\
IV & 3 & $1,2,15$ & 636 & $32^{\circ} 18^{\prime}$ & $70^{\circ} 45^{\prime}-70^{\circ} 47^{\prime}$ \\
V & 1 & 10 & 579 & $32^{\circ} 17^{\prime}$ & $70^{\circ} 45^{\prime}$ \\
VI & 1 & 11 & 729 & $32^{\circ} 25^{\prime}$ & $71^{\circ} 06^{\prime}$ \\
VII & 1 & 18 & 523 & $32^{\circ} 16$ & $70^{\circ} 45^{\prime}$ \\
\hline
\end{tabular}

Table 2: Representative plant species with local names and average IVI in communities

\begin{tabular}{|c|c|c|c|c|c|c|c|c|}
\hline \multirow[b]{2}{*}{ Indicator species } & \multirow[b]{2}{*}{ Local name } & \multicolumn{7}{|c|}{ Communities } \\
\hline & & I & II & III & IV & $\mathrm{V}$ & VI & VII \\
\hline Acacia modesta & Palosa & 36.82 & 27.92 & 20.47 & 18.95 & 28.87 & 0.0 & 0.0 \\
\hline Olea ferruginea & Shwawan & 28.66 & 36.39 & 7.67 & 0.0 & 0.00 & 0.0 & 8.87 \\
\hline Acacia nilotica & Kikar & 1.819 & 3.20 & 21.65 & 9.82 & 5.53 & 19.69 & 19.78 \\
\hline Capperis decidua & Kir'ra & 9.37 & 3.07 & 7.66 & 36.32 & 5.48 & 0.00 & 0.00 \\
\hline Tecomella undulata & Wredan & 5.66 & 2.41 & 4.36 & 1.16 & 17.82 & 7.14 & 8.30 \\
\hline Prosopis cineraria & Sangara & 0.00 & 4.80 & 6.80 & 0.0 & 0.00 & 21.80 & 15.78 \\
\hline Ziziphus jujuba & Bira & 4.32 & 7.45 & 5.91 & 11.79 & 8.95 & 18.97 & 9.14 \\
\hline Eucalyptus lanceolatus & Lachaie & 3.42 & 3.65 & 3.45 & 7.78 & 0.0 & 15.83 & 14.72 \\
\hline Salvadora oloides & Plamon & 4.69 & 0.0 & 7.93 & 0.0 & 0.0 & 12.56 & 0.0 \\
\hline Melia azedarach & Bakanra & 3.83 & 4.92 & 1.42 & 3.74 & 0.0 & 1.75 & 0.0 \\
\hline Dalbergia sissoo & Shawa & 4.08 & 2.79 & 5.83 & 8.22 & 0.0 & 0.0 & 0.0 \\
\hline Tamarix aphylla & Ghaz & 0.0 & 0.0 & 3.38 & 1.16 & 32.35 & 0.0 & 0.0 \\
\hline Ailanthus altissima & Bakanra & 0.0 & 0.0 & 3.6 & 0.0 & 0.0 & 0.0 & 20.41 \\
\hline
\end{tabular}

Thus as a result of analysis 7 communities of woody tree species were established in the SBNP, Dera Ismail Khan, Pakistan, which are given in Table 2.

Acacia modesta and Olea ferruginea community: This community was established at an altitude ranged from 304-1327 meter above sea level and was represented by 10 stands, 225 quadrates and 19 trees species. Stands named as Khlaso Thalab, Lande Sar, Sra Ghara, Nishpo Laar, Chapara, Bara khan, Angriz Qabristan, Janrawonaie, Darkhi Wanda and Azar Thalab. The slope angle of these communities ranged from $20-45^{\circ} \mathrm{C}$. Generally the stands were in South, West and South West direction. The latitude ranged from $32^{\circ} 16^{\prime}-32^{\circ} 33^{\prime}$ and longitude ranged from $70^{\circ} 00^{\prime}-70^{\circ} 49^{\prime}$. In all these stands, Acacia modesta was the dominant with mean species dominance of $36.82 \%$ followed by Olea ferruginea with IVI $28.66 \%$. The average IVI values are presented in Table 2.

Olea ferruginea and Acacia modesta community: The Olea community was represented by 7 stands and 27 tree species of SBNP. Olea ferruginea was the dominant tree species of the park in 7 stands named as Balooldana ghundaie, Khawraie, Thoorey Khawrey, Kamtherey koor, Dris thalab, Miss coat, Dockbangla. All these stands at 463-1339 meter altitude, latitude from $32^{\circ} 16^{\prime}$-to $32^{\circ} 30^{\prime}$, longitude from $71^{\circ} 00^{\prime}-71^{\circ} 49^{\prime}$. Generally the stands were north and north east side facing with slope angle $20^{\circ}-50^{\circ}$. Olea ferruginea was the dominant species and Acacia modesta was co-dominant while Acacia nilotica was the dominant species. The important average values are given in Table 2.

Acacia nilotica and Acacia modesta community: This community was represented by 6 stands and 19 woody tree species of the study area. Acacia nilotica was the dominant plant community of 6 stands named as Rospino thangaie, Qolinishpa, Gundakee Ghashaie, Sheri qamar, Shin ghar and Machar danas. These stands were situated at 273- 569 elevation, $32^{\circ} 24^{\prime}-32^{\circ} 34^{\prime}$ latitude and $71^{\circ} 05^{\prime}-71^{\circ} 12^{\prime}$ longitude, the slope angle ranged from $25^{\circ}-50^{\circ}$. The aspect of the majority stands was east, north east and south. The dominant tree specie in these stands was Acacia nilotica while the co-dominant specie was that of Acacia modesta.

Caperis decidua and Acacia modesta community: This community was represented by 3 stands and 11 tree species of the park area. Capparis decidua was dominant in 3 stands (1, 2 and 15) named as Thangaie, Lote Ghondaie, Gugu chuka in the 29 stands of the study area. These sites were located from 454-899-- meter elevation, $32^{\circ} 18^{\prime}$ latitude and from $70^{\circ} 45^{\prime}-70^{\circ} 47^{\prime}$ longitude and West, South and South East side facing, slope angles were from $25-45^{\circ} \mathrm{C}$. Caperis decidua was the dominant species, while Acacia modesta was the co-dominant tree specie.

Tamarix aphylla and Acacia modesta community: This community was represented by 1 stand, 25 plots 
Sci. Technol. Dev., 35 (2): 67-74, 2016

and 6 tree species of the study area. Tamarix aphylla was dominant in the stand No. 10, named as Hasham thangaie. The site was located at 579 meter above sea level, $32^{\circ} 17^{\prime}$ latitude and $70^{\circ} 45^{\prime}$ longitude facing North East with slope angle $20^{\circ} \mathrm{C}$. The co-dominant species of the stand was Acacia modesta.

Prosopis cineraria and Acacia nilotica community: The Prosopis cineraria community was represented by one stand 25 plots and 7 trees species of the park area. Prosopis cineraria specie was dominant in the stand No. 11, named as Zoor chakar, which was situated at 729 meters above sea level, $32^{\circ} 25^{\prime}$ latitude and $71^{\circ} 06^{\prime}$ longitude, south facing with $25^{\circ} \mathrm{C}$ slope angle. Acacia nilotica was the 2nd dominant specie of the stand with 18.69 IVI value.

Ailanthus altissima and Acacia nilotica community: It was represented by 1 stand, 25 plots and 8 tree species of the study area. Ailanthus altissima community was dominant with 20.41 IVI value in the stand No. 18, which was named as Zindan. The stand was situated at 523 meters above sea level with coordinates $32^{\circ} 16^{\prime} \mathrm{N}$ and $70^{\circ} 49^{\prime} \mathrm{E}$. The co-dominant specie of the stand was Acacia nilotica with $19.78 \mathrm{IVI}$.

The 13 most frequently occurring tree species in Sheikh Buddin National Park were Acacia modesta, Olea ferruginea, Acacia nilotica, Caperis decidua, Tamarix aphylla, Prosopis cineraria, Ailanthus altissima, Ziziphus jujube, Eucalyptus lanceolatus, Salvadora oloides, Melia azedarach, Dalbergia sissoo and Monotheca buxifolia while Cordia myxa, Ficus carica, Ficus palmata, Grewia optiva, Morus alba, Morus nigra, Nannorrhops ritchiana, Phoenix dactylifera, Pistacia chinensis, etc., were rare species.

The average IVI of Acacia modesta was the highest in community I, which was 36.82 and second in community II (27.92). Similarly the average important value index of Olea ferruginea was the highest in community II (36.39) followed by community I (28.66). Acacia nilotica in community III (IVI 21.65), Capperis decidua in community IV (36.32), Tecomella undulata in community V (17.82), Prosopis cineraria 21.8 in community VI, Ziziphus jujuba in VI (18.97), Eucalyptus lanceolatus in community VI (15.83), Salvadora oloides 12.56 in community No. VI, Melia azedarach 4.92 in community II, Dalbergia sissoo 8.22 in community IV, Tamarix aphylla 32.35 in the community V and Ailanthus altissima with average IVI 20.41 in the community VII.

Diversity and Similarity among communities: Similarly, the diversity values were determined. It is clear from Table 3 that the number of species is the highest in
Table 3: Showing diversity values

\begin{tabular}{|c|c|c|c|c|c|c|c|}
\hline \multirow[b]{2}{*}{ Diversity values } & \multicolumn{7}{|c|}{ Communities } \\
\hline & I & II & III & IV & $\mathrm{V}$ & VI & VII \\
\hline $\mathrm{N}$ & 15.6 & 19.28 & 19.66 & 13.33 & 17.0 & 18.0 & 19.0 \\
\hline $\mathrm{D}$ & 0.08 & 0.102 & 0.074 & 0.11 & 0.09 & 0.075 & 0.137 \\
\hline $\mathrm{H}^{\prime}$ & 2.59 & 2.65 & 2.66 & 2.79 & 2.61 & 2.38 & 2.62 \\
\hline M & 22.81 & 22.68 & 21.27 & 28.16 & 23.29 & 27.88 & 21.68 \\
\hline $\mathrm{J}$ & 0.94 & 0.89 & 0.86 & 1.09 & 1.08 & 0.79 & 0.89 \\
\hline$\underline{S}$ & 1.18 & 1.37 & 1.55 & 1.15 & 1.22 & 1.23 & 1.35 \\
\hline
\end{tabular}

Table 4: Sorenson similarity co-efficient of the plant communities

\begin{tabular}{llllllll}
\hline & I & II & III & IV & V & VI & VII \\
\hline I & & & & & & & \\
II & 90 & & & & & & \\
III & 90 & 90 & & & & & \\
IV & 84 & 84 & 76 & & & & \\
V & 62 & 62 & 55 & 80 & & & \\
VI & 62 & 62 & 66 & 53 & 50 & & \\
VII & 58 & 70 & 73 & 50 & 46 & 76 & \\
\hline
\end{tabular}

community III and Simpson diversity was the highest in the community VII. Shannon diversity, Maturity index, Evenness values were the highest in the community IV, while Richness value (1.55) was the highest in community III.

Table 3 represented that the number of species was highest in community III (19.66), Simpson diversity was maximum in community (0.137), Shannon diversity (2.79), maturity index was highest (28.16) in community IV followed by (27.88) in community VI, evenness (1.09) were maximum in community IV followed by (1.08) in community $\mathrm{V}$, while the species richness values appeared to be different among all 7 communities, ranging from 1.15-1.55.

Similarly, the Sorenson similarity index, which measures the degree of similarity or dissimilarity of communities of samples or species composition of the forest or of different forests was calculated. Thus, similarity of species composition observed slightly varied among communities. Table 4 shows that the highest similarity observed between communities I and II, I and III and also between II and III (90\%) means that most of the plants are same in these communities, followed by $84 \%$ similarity index observed between community I and IV and also between II and IV, while the least similarity (46\%) was observed between the community V and VII. Overall, the similarity coefficient ranged from $90-46 \%$. Thus species composition dissimilarity of the most similar communities accounts for 10 and $54 \%$ of those that share least similarities.

Community composition and species composition are determined and regulated by a variety of anthropogenic and environmental factors (Dolezal and Srutek, 2002). Anthropogenic interferences like overgrazing, lumbering and forest encroachments are some of the major factors 
controlling species distribution (Dombois and Ellenberg, 1974). In a specific area the biodiversity is contributed by the flora richness both in the number of species and variety of different plants communities while some problems are studied and resolved on utilization and conservation basis which are urgent and necessary (Chaugthai and Yousaf, 1976; Khan et al., 2011b). A total of 26 tree species of 22 genera's and 19 families were stated from the study area. In general, the whole area of SBNP is considered as the Acacia modesta and Olea ferruginea community, in which Ziziphus jujuba is associated as a 3rd dominating specie in most of the communities. Most species of SBNP are similar to those of the neighboring regions such as that of Districts Tank (Badshah et al., 2013), Karak (Khan et al., 2012), Lakki Marwat (Zahoor et al., 2009) and district Bannu (Wazir et al., 2010). It is clear from Table 2 that Acacia modesta was the most occurring tree species of the study area as it was dominant in one community, while co-dominant in 4 communities out of seven communities with average IVI 19.004 followed by Olea ferruginea with average IVI value 11.65.

It may be attributed that differences in the soil, topography and environmental factors result in the variations in species richness, diversity, maturity and evenness among different ecological communities (Zuo et al., 2012; De Bello et al., 2013; Saqib et al., 2011). Species richness and species diversity calculated was (1.35-1.15), (2.59-2.79), respectively. Species richness particularly at moderate elevation increases, but there is a tendency towards declination beyond altitudinal range (Giriraj et al., 2008). Our results agree with their findings, especially at community III, showing the highest species richness (1.55) at an average 417 meter above sea level.

The Shannon-Weiner diversity index usually ranges from 1.5-3.5 and hardly exceeds 4.5 (Kent and Coker, 1992). Same is the case of SBNP, where it ranged from 2.59-2.79 showing that the diversity is normal here.

\section{CONCLUSION}

Based on the current study, it is suggested that SBNP and its trees species need proper management, care and protection. The local community should be involved for the participatory forest management programs to create awareness and sense of ownership so that local communities take responsibility for the management, care, protection, conservation and reproduction of the forest trees and as a result of this activity, it will become beneficiary of the economic payback. Continued and prolonged human disturbances may eliminate these ecologically important forest and park forever. Further research is needed to be carried out on the regeneration status of the park trees and vegetation and soil characteristics of the park area.

\section{REFERENCES}

Abbas, F.I., T. Akhtar and A. Mian, 2009. Phytosociological analysis within the range of grey goral in Pakistan and Azad Kashmir. Pak. J. Bot., 41: 667-682.

Ahmad, S.S. and Q.U. Ann, 2011. Exploring the vegetation dynamics and community assemblage in Ayubia National Park, Rawalpindi, Pakistan, using CCA. Biodiv. J., 2: 115-120.

Ahmad, S.S., S. Erum, S.M. Khan and M. Nawaz, 2014. An appraisal of ecological distribution of herbaceous flora at Changa Manga park Lahore, Pakistan. Pak. J. Bot., 46: 19-25.

Ahmed, S.S., S. Fazal, E.E. Valeem, Z.I. Khan, G. Sarwar and Z. Iqbal, 2009. Evaluation of ecological aspects of road side vegetation around Havalian city using multivariate techniques. Pak. J. Bot., 41: 53-60.

Ali, S.I. and M. Qaiser, 1995-2005. Flora of Pakistan. Fakhri Printing Press, Karachi, Pakistan.

Badshah, L., F. Hussain and Z. Sher, 2013. Floristic inventory, ecological characteristics and biological spectrum of rangeland, District Tank, Pakistan. Pak. J. Bot., 45: 1159-1168.

Belayneh, A. and S. Demissew, 2011. Diversity and population structure of woody species browsed by elephants in Babile Elephant Sanctuary, eastern Ethiopia: An implication for conservation. Ethiopian e-J. Res. Innov. Foresight, 3: 20-32.

Brown, R.T. and J.T. Curtis, 1952. The upland conifer-hardwood forests of Northern Wisconsin. Ecol. Monographs, 22: 217-234.

Chaugthai, S.M. and M. Yousaf, 1976. The ecology of the native vegetation of Kohat, NWFP. Pak. J. Bot., 8: 27-36.

Curtis, J.T. and G. Cottam, 1956. Plant Ecology Work Book: Laboratory Field Reference Manual. Burgess Publishing Co., Minnesota, pp: 193.

Curtis, J.T. and R.P. McIntosh, 1950. The interrelations of certain analytic and synthetic phytosociological characters. Ecology, 31: 434-455.

De Bello, F., S. Lavorel, S. Lavergne, C.H. Albert, I. Boulangeat, F. Mazel and W. Thuiller, 2013. Hierarchical effects of environmental filters on the functional structure of plant communities: A case study in the French Alps. Ecography, 36: 393-402.

Deguignet, M., D.J. Bignoli, J. Harrison, B. MacSharry, N. Burgess and N. Kingston, 2014. United nations list of protected areas. United Nations Environment Programme, WCMC, Cambridge, UK. 
Dolezal, J. and M. Srutek, 2002. Altitudinal changes in composition and structure of mountain-temperate vegetation: A case study from the Western Carpathians. Plant Ecol., 158: 201-221.

Dombois, D.M. and H. Ellenberg, 1974. Aims and Method of vegetation Ecology. John Wiley and Sons, New York, ISBN: 9780471622901, Pages: 200.

Giriraj, A., M.S.R. Murthy and B.R. Ramesh, 2008. Vegetation composition, structure and patterns of diversity: A case study from the tropical wet evergreen forests of the Western Ghats, India. Edinburgh J. Bot., 65: 447-468.

Hameed, M., A.A. Chaudhry, M.A. Maan and A.H. Gill, 2002. Diversity of plant species in Lal Suhanra national park, Bahawalpur, Pakistan. J. Biol. Sci., 2: 267-274.

Hussain, A., M. Ahmed, S.S. Khan, M. Akbar and M.U. Zafar, 2013. Future trends of the vegetation from Central Karakoram National Park, Gilgit-Baltistan, Pakistan. Sci. Technol. Dev., 32: 165-181.

Hussain, A., M.A. Farooq, M. Ahmed, M.U. Zafar and M. Akbar, 2010. Phytosociology and Structure of Central Karakoram National Park (CKNP) of northern areas of Pakistan. World Applied Sci. J., 9: 1443-1449.

IUCN., 1990. IUCN directory of south asian protected areas. World Conservation Monitoring Centre, Cambridge, UK.

Jabeen, T. and S.S. Ahmad, 2009. Multivariate analysis of environmental and vegetation data of Ayub national park Rawalpindi. Soil Environ., 28: 106-112.

Kent, M. and P. Coker, 1992. Vegetation Description and Analysis: A Practical Approaches. Belhaven Press, London, UK., Pages: 363.

Khan, M., F. Hussain and S. Musharaf, 2012. Biological characteristics of plant species in Tehsil Takht-e-Nasrati, Pakistan. J. Biol. Environ. Sci., 2: 42-47.

Khan, N., M. Ahmed, A. Ahmed, S.S. Shaukat, M. Wahab, M. Ajaib, M.N. Siddiqui and M. Nasir, 2011a. Important medicinal plants of Chitral Gol National Park (CGNP) Pakistan. Pak. J. Bot., 43: 797-809.

Khan, S.M., D. Harper, S. Page and H. Ahmad, 2011b. Residual value analyses of the medicinal flora of the western Himalayas: The Naran valley, Pakistan. Pak. J. Bot., 43: 97-104.

Marwat, S.K. and M.A. Khan, 2008. Biodiversity of sedges in Dera Ismail Khan District, NWFP Pakistan. Sarhad. J. Agric., 24: 293-303.
Marwat, S.K., M.A. Khan, M. Ahmad, M. Zafar and K. Usman, 2012. Floristic account of the asclepiadaceous species from the flora of Dera Ismail Khan District, KPK, Pakistan. Am. J. Plant Sci., 3: 141-149.

Menhinick, E.F., 1964. A comparison of some species-individuals diversity indices applied to samples of field insects. Ecology, 45: 859-861.

Nasir, E. and S.I. Ali, 1971-1975. Flora of West Pakistan. National Herbarium Islamabad.

Nizami, A.R. and R.A. Sheikh, 2009. Microfacies analysis and diagenetic settings of the middle Jurassic Samana Suk Formation, Sheikh Budin Hill section, trans Indus ranges-Pakistan. Geol. Bull. Punjab Univ., 44: 69-84.

Philips, E.A., 1959. Methods of Vegetation Study. Henry Holt Co. Inc., New York, USA., Pages: 107.

Pielou, E.C., 1969. An Introduction to Mathematical Ecology. Wiley Interscience, New York, pp: 286.

Rasheed, F., S. Hafeez and I.Q. Bhabha, 2005. Phyto-sociological study and determination of carrying capacity of the reserve forest compartment-17 of Margallah hills national park. Pak. J. Agri. Sci., 42: 71-74.

Saqib, Z., R.N. Malik, M.I. Shinwari and Z.K. Shinwari, 2011. Species richness, ethnobotanical species richness and human settlements along a Himalayan altitudinal gradient: Prioritizing plant conservation in palas valley, Pakistan. Pak. J. Bot., 43: 129-133.

Shaheen, H., R.A. Qureshi and Z.K. Shinwari, 2011. Structural diversity, vegetation dynamics and anthropogenic impact on lesser Himalayan subtropical forests of Bagh district, Kashmir. Pak. J. Bot., 43: 1861-1866.

Shannon, C.E. and W. Weaver, 1949. The Mathematical Theory of Communication. University of Illinois Press, Urbana, Chicago, pp: 35.

Shaukat, S.S., M.A. Khan, M. Mett and M.F. Siddiqui, 2014. Structure, composition and diversity of the vegetation of Hub dam catchment area, Pakistan. Pak. J. Bot., 46: 65-80.

Simpson, E.H., 1949. The measurement of diversity. Nature, 163: 688-688.

Sorenson, T., 1948. A method of establishing groups of equal amplitude in plant sociology based on similarity of species and its application to analyses of the vegetation on Danish commons. Biol. Skrifter, 5: 1-34.

Ullah, A., N. Khan and Z. Muhammad, 2015. Diversity of life form and leaf size classes at Sheikh Buddin National Park, Dera Ismail Khan, Khyber Pakhtunkhwa Pakistan. S. Asian J. Life Sci., 3: 6-13. 
Wazir, A., S. Mehmood and A. Farooq, 2010. Ethnobotanical survey of plants of Kurram river beds of district Bannu, Pakistan. Pak. J. Plant Sci., 16: 22-25.

Zahoor, M., S.M. Wazir, A. Mohammad and S. Mohammad, 2009. Ethnobotany of some plants from Darra'e Pezo, District Lakki Marwat, Pakistan. Pak. J. Plant Sci., 15: 75-80.
Zuo, X.A., J.M.H. Knops, X.Y. Zhao, H.L. Zhao, T.H. Zhang, Y.Q. Li and Y.R. Guo, 2012. Indirect drivers of plant diversity-productivity relationship in semiarid sandy grasslands. Biogeosciences, 9: $1277-1289$. 